\title{
The New Global Labour Studies: A Critical Review
}

\author{
Marissa Brookes, University of California Riverside, USA \\ Jamie K. McCallum, Middlebury College, USA
}

\begin{abstract}
The past two decades have seen a dramatic upsurge in sustained, cross-border labour activism, or labour transnationalism. Scattered across multiple disciplines and subfields, a new field of inquiry the new global labour studies (NGLS) - has emerged as scholars seek to comprehend the causes and consequences of twenty-first-century labour transnationalism. This multi-disciplinary approach has provided a platform from which to analyse an emerging phenomenon. We assess relevant strands of this emerging field that focus on: a) new theories of labour power and corporate vulnerability, and b) worker agency and organising strategy. While these areas have produced robust findings, we argue that developing a more complete understanding of labour transnationalism and its outcomes will require scholars to produce a more explicit critique of mainstream political economy, sociology, political science and labour studies.
\end{abstract}

\section{KEY WORDS}

Labour; labour movements; globalisation; transnationalism; labour transnationalism; unions

\section{The New Global Labour Studies: A Critical Review}

The past two decades have seen a dramatic upsurge in sustained, cross-border labour activism, or labour transnationalism. Spanning North-South divides, industrial and service economies, and racial and gender lines, workers and their organisations have attempted, sometimes successfully, to meet capital at its own scale. To date over 115 global framework agreements (GFAs) have been signed by transnational corporations (TNCs) and the recently re-branded Global Unions. The latter expanded significantly in the early 2000s following their transformation from the old International Trade Secretariats into Global Union Federations. Workers and unions from different countries are also increasingly involved in less formal modes of transnational collaboration, ranging from basic alliancebuilding efforts to more elaborate, employer-targeted campaigns.

Through these actions transnational activists have collectively built the inchoate foundation of a new kind of labour movement. Scholars argue that, in contrast to the past, the new spirit of labour transnationalism strives for greater democracy, diversity and inclusivity, and tries to emphasise direct, concrete solidarity actions informed by strategic research and decentralised information networks.

Global Labour Journal, 2017, 8(3), Page 201 
Though these efforts are not always successful, most literature, including our own research, has intimated a shift toward a greater strategic crossover between social movements and more institutionalised actors. In their efforts to restructure employment relations under global capitalism, participants in the new labour transnationalism self-consciously reject the view that workers are mere victims of globalisation and instead aim to steer economic globalisation toward more equitable ends. Labour transnationalism is therefore significant not only from an employment relations perspective but also to all those interested in the future direction and shape of global capitalism. Not surprisingly, then, this phenomenon has captured the attention of scholars in fields as diverse as geography, sociology, political science, economics and law. We thus see the emergence of a new field of inquiry - the new global labour studies (NGLS).

Does the hodgepodge of disciplinary foci mean the field lacks a coherent conceptual focus? We see the interdisciplinary nature of the NGLS as its most noteworthy characteristic. Speaking across disciplines is not easy, however. Hence, one purpose of this article is to identify barriers that may inhibit theoretical development in the NGLS and to offer specific solutions for moving forward. We first provide a brief historical orientation to scholarship on new labour transnationalism. Next, we highlight two major subsets of NGLS scholarship: one theoretical strand, inspired by Marx and Polanyi, which attempts to recast labour transnationalism as a countermovement to reshape global capitalism, and another that examines individual cases of labour transnationalism and the specific strategies unions have adopted to challenge corporate power. The labour-as-countermovement strand occasionally suffers from a tendency to assume that several individual instances of transnational action comprise a single global movement, while the strategy-focused strand often lacks a robust connection to theory.

We therefore suggest a combined approach, one geared toward generating broad theory, while still accounting for the specific strategies labour activists use on the international scale - in other words, a middle-range approach. Doing so, however, will require researchers to more clearly and consistently conceptualise what labour transnationalism is and which instances of it are directly comparable. Moreover, scholars should begin to more consciously situate the strategies workers use to engage employers on the international scale in current debates in sociology and political science over the dynamics of transnational activism, the institutions shaping corporate strategy and the viability of private governance. This will help NGLS scholars develop a more critical lens through which to assess the impact labour transnationalism has had on inequality, institutions and other important outcomes. Rather than undertake a comprehensive look at this literature, which is already quite large and growing, we aim here to hone in on the strands we feel are most influential, likely to grow and most controversial.

To be clear, the present article does not assume there exists any unitary "global labour movement". Rather, the NGLS refers to a growing mass of scholarship that examines a variety of phenomena characterised by union and worker collaboration across national borders. Moreover, we acknowledge that one may rightfully question what about the NGLS is truly "new". Arguably, at best, the concept of newness signals that a phenomenon of historical significance has present-day 
salience. At worst, the newness concept serves as a tautological device that discourages serious investigation into which forms of transnational action are actually becoming dominant over older, less progressive forms. The following brief historical orientation is thus intended to clarify the "newness" aspect of the NGLS and to set it apart from other subfields.

\section{From Internationalism to Globalism: What's New About the New Labour Transnationalism?}

The fatalism of the Thatcher-Reagan decade saw unions in the industrialised North in decline and social movement unionism gathering momentum in the South. In this milieu, the New International Labour Studies (NILS) movement emerged with a formidable critique of mainstream political economy and global commodity chain approaches, injecting labour into the analysis of globalisation, an area where it had been conspicuously absent (Munck, 1988). NILS proponents assembled a body of literature advancing a theoretical paradigm that expanded the traditional industrial relations outlook to include insights into the uneven geographic division of labour, the social reproduction of inequality, class stratification, informalisation and new identity formation, anticipating some concerns that would later be raised by theorists of union renewal and social movement unionism (Cohen, 1980; Cornfield and McCammon, 2003).

The economic and political crises confronting workers continued into the 1990s, creating new difficulties for vulnerable workers in the North and for incipient unions in the South. A group of scholars thus began at that time to pursue a series of different but related questions. It is this generation who formed the core theories that constitute the "new labour transnationalism" or "new global labour studies" literature. This literature distinguishes modern labour transnationalism from the "old" internationalism that began in the nineteenth century and lasted until the last decade of the twentieth century. The old internationalism was vested in large, (mostly) European trade union bureaucracies, political parties and other bureaucratic organisations, such as the industry-wide International Trade Secretariats and the International Confederation of Free Trade Unions (ICFTU). "New" variants are said to have sprung from social movement forces inspired by actors in the Global South, who place a stronger emphasis on decentralised and horizontal information networks, multidirectional flows of support and direct worker solidarity actions (Waterman, 2001; Webster, Lambert and Beziudenhout, 2008).

The slight difference in language matters - from NILS to NGLS. Whereas the former sees national labour movements interacting across their respective borders, the newer group of scholars has been more likely to imagine a truly cosmopolitan or global movement constituted by workers with increasingly tenuous ties to their home countries, nation-states and national labour movement traditions. While we recognise this dimension as somewhat disconnected from the lived experiences of many workers, the sensibility is nonetheless present between the lines in the literature.

Peter Waterman was the first and most enthusiastic exponent of the "newness" idea, having

published a series of working papers and essays on the topic as early as 1984 - while the "old"

Global Labour Journal, 2017, 8(3), Page 203 
internationalism was still very much alive - although his typologies have been updated. By and large, however, it is often argued that the new labour transnationalism takes the form of a "rhizomatic organisation" committed to a democratic, decentralised network of activists, as opposed to a "treelike" union bureaucracy, which is top-down (Evans, 2010). While not all of these characteristics are grounded in empirical observation, Waterman's propositions opened the door to further discussions about the possibilities for a global, counter-hegemonic labour movement.

The end of the Cold War eased ideological tensions among labour organisations, thus allowing workers in both developed and developing countries to refocus their attention on the spread of neoliberal capitalism (Moody, 1997; Harrod and O’Brien, 2002: 6). Among the most optimistic about the prospects for a global labour movement were those who saw economic globalisation as creating a worldwide class-in-itself with a collective interest in thwarting whipsawing and other divisive corporate tactics (Moody, 1997; Mazur, 2000). At times, major changes in the structure of international organisations appeared to support these claims. In 1994, a European Union Directive established European Works Councils, enabling national-level unions and works councils to share information with each other and coordinate their communication with top management of companies operating across multiple European states. Meanwhile, the old International Trade Secretariats reformulated themselves into the Global Union Federations, and the ICFTU merged with the World Confederation of Labour to form the International Trade Union Confederation (ITUC) in 2006.

Nevertheless, despite these organisational transformations and an increasing number of labour-led campaigns targeting transnational corporations (discussed below), it remains unclear what all of this means for labour's future. Union densities have continued to fall almost everywhere, including (and sometimes especially) within those unions most committed to transnationalism. Theorists have been trying to make sense of these dynamics ever since, and it is to their efforts that we now turn.

\section{Marx, Polanyi and the New Global Labour Studies}

Marxism casts a long shadow over the NGLS. Whether they concern themselves with the general idea of the world's workers uniting or the specific notion of capitalism paradoxically sowing the seeds of its own destruction, NGLS scholars frequently find Marxian approaches serving as a background condition. One might thus say that most NGLS scholars are at least "Marx-ish". At the same time, however, the decline of Marxism in academic circles (especially in the United States) has impacted labour studies, making room for what is, by and a large, a more moderate socialist position. One approach along these lines has been directly inspired by Karl Polanyi, whose insights have been interpreted as offering some cautious optimism about prospects for labour's renewal.

Writing during World War 2, Polanyi provided a global perspective that can now be seen as ahead of its time. He claimed that the foundations of nineteenth-century society, particularly the nation-state and the self-regulating market, produced contradictory effects. Hence, a response came 
in the form of spontaneous uprisings demanding that governments protect society "against the perils of the self-regulating market system" by re-embedding the market in a variety of collectivist projects: fascism, communism, Stalinism and the New Deal (Polanyi, 2001: 80). Polanyi called this disembedding of markets from society and subsequent re-embedding following the demands of a countermovement "the double movement".

Polanyi's historical perspective raises an obvious question for today: What forces will arise to discipline the market sufficiently to allow society a greater degree of control over the political economy in the current period of neo-liberalism? According to Beverly Silver (2003), whose Forces of Labor combines Marxian and Polanyian analyses, these forces come in the form of both "Marx-type" and "Polanyi-type" labour unrest. The Marx-type corresponds with emerging working-class struggles against exploitation, such as those in China; the Polanyi-type relates to, for example, anti-austerity protests against commodification in Europe. Although Forces of Labor is not, strictly speaking, an analysis of transnational labour cooperation, it has inspired a great deal of NGLS scholarship (e.g. Bieler and Lindberg, 2010). Similarly, Grounding Globalisation (Webster et al., 2008), a book by three leading scholars of labour struggles in the Global South, begins with an assessment of the "Polanyi Problem" and is organised in Polanyian style - a teleology between society and the market, even while holding out for, as one reviewer described it, "the promise of sociological Marxism" (Stevis, 2009).

Peter Evans' (2008) article on "counter-hegemonic globalisation" is directly inspired by Polanyi's countermovement thesis. Yet by the arrival of Evans' 2010 article - "Is It Labour's Turn to Globalize" - Polanyi was scarcely mentioned, save for a reference to Ronaldo Munck. Munck (2002) subtitled his book The New Great Transformation and probably more than anyone is responsible for the move toward Polanyian themes in the NGLS. Drawing parallels between the labour movements that successfully re-embedded the market in Polanyi's time and the transnational labour movement of sixty years later, Munck argues that these movements signal a turning point in the development of modern anti-capitalism. "It may, indeed, simply be the case that the hour of von Hayek is gone and the hour of Polanyi has arrived" (Munck, 2002: 177-178).

Part of the allure of Polanyi's framework is that it allows for uncoordinated and disaggregated labour movements to reflexively retaliate against the market, much as the body reacts to fight disease. "For each victory of the transnational capitalist class", writes Munck, "there is a new blow struck from below through a strike, a consumer boycott, or a legal challenge to their hegemonic role" (Munck, 2002: 178-179). The leading activist-scholar of the US labour movement has proffered the Polanyian line as well. Stephen Lerner, a former leader of the Service Employees International Union, argued that "the spread of multinational corporations and the increasing concentration of capital have created the conditions that can turn globalisation on its head" (Lerner, 2007: 17). It is no mere coincidence that Polanyi's work has enjoyed a revival alongside more recent texts that popularised similar social movement possibilities. Hardt and Negri (2001: xiii) have suggested, for example, that the "multitude", the amorphous counter-insurgency against global capitalism, is a "living alternative that grows within Empire". Polanyi's framework is understandably seductive to

Global Labour Journal, 2017, 8(3), Page 205 
scholars trying to make sense of both the contradictions of capitalist globalisation and the rise of global labour struggles. It has, in many important ways, provided the foundational theory for the development of the new labour transnationalism discourse.

Nevertheless, the interest in Polanyi also provoked a number of rebuttals. In a critical review essay - "From Polanyi to Pollyanna: The False Optimism of Global Labour Studies" - Michael Burawoy spares almost no one: Peter Evans (2008) "clutches at straws"; Gay Seidman (2008) is seduced by "the Nirvana principle"; the authors of Grounding Globalisation enter into "a flight of fancy into labour internationalism and utopian society" (Burawoy, 2010: 302-305). In contrast to their overriding optimism, Burawoy (2010: 312) suggests we take up an "uncompromising pessimism". While many scholars argue that the contradictions of global capitalism have, in effect, readied the terrain for another double movement, Burawoy insists on nearly the opposite. He wants to inject "a careful and detailed analysis of the way capitalism combines the commodification of nature, money and labour, and thereby destroys the very ground upon which a 'countermovement' could be built" (Burawoy, 2010: 312).

Through a series of replies to Burawoy in this journal, Dan Clawson (2010) makes a principled "defence of false optimism", while others argue against his interpretation of Polanyi. Nevertheless, Burawoy does make an important point: Most attempts to win gains through cross-border organising alliances and international bargaining collapse under numerous obstacles, and there are too few cases of meaningful victories for workers on the international scale to point to a counter-hegemonic globalisation.

The optimistic perspective of so many scholars, as well as Burawoy's scepticism, are equally understandable, but both miss the point. Crucially, there is very little in Polanyi's corpus to suggest who or what will comprise the countermovement. Workers, let alone strategic labour transnationalism, played no special role in the spontaneous, society-wide countermovement described in The Great Transformation. As an unplanned backlash, the countermovement entailed little deliberate networking or attempted interconnectedness. This is not to say that labour movements did not matter, but they were only ever one part of the larger whole.

Despite Polanyi's polemics against Marx's allegedly mechanised recipe for revolution, Polanyi's own work is perhaps too easily read as a formulaic social change theory. Yet whether a global countermovement is arising, and whether labour is central to it, has less to do with any particular reading of Marx or Polanyi. It is ultimately an empirical question. Neither the labour-ascountermovement view nor Burawoy's critique adequately explain bow those rare occasions of successful labour transnationalism happen. That question, we argue, is first and foremost about strategy, a focus of another strand of NGLS scholars.

\section{Transnational Strategies in the New Global Labour Studies}

While there is a clear bias in the literature for the position that labour can and should match capital at a global scale, how to do so is very much up for debate. Strategy-focused scholars agree that today's 
transnational strategies are different from those of the old labour internationalism, as workers are reacting to new structural changes in the global economy. One early approach to examining transnational labour strategies connected transnational labour cooperation to theories of social movements, with Waterman (1998), among others, advocating for internationalism on the shop floor and from the grass roots. Likewise, Moody's (1997) Workers in a Lean World concluded with a principled call for bottom-up organising and union education networks, an approach that resonated with scholars in search of a globalisation from below. This perspective gained momentum after the 1999 protests against the World Trade Organization (WTO) in Seattle, where unionists from different countries shared the stage and streets with students, environmentalists, feminists and community groups. The protest helped solidify, if only for a moment, the idea that labour had "moved beyond a conception of transnational collective bargaining" and towards "a more 'social movement' unionism"' (Munck, 2002: 154). In the protest's aftermath, Jay Mazur, then director of the AFL-CIO's foreign affairs committee, captured the spirit of this sentiment well: "A social movement of potentially tremendous force has begun to gather that can affect the bottom line [of corporations] and the laws of the land" (Mazur, 2000: 8). It was also bolstered by the crosspollination of movement strategies that emerged out of the transnational anti-apartheid movement and Central American solidarity movements.

Nonetheless, the idea that transnational labour activists were becoming "more like social movements" proved to be more prescriptive than descriptive. Another segment of strategy-focus scholars thus turned to case studies of transnational campaigns to gain a more empirically accurate view of the new labour transnationalism. These case studies included: the United Steelworkers' dispute with the Ravenswood Aluminum Corporation in 1995, in which consumer boycotts and political demonstrations by unions in twenty-eight countries aided the Steelworkers' victory (Herod, 1995; Juravich and Bronfenbrenner, 1999); the 1996-1998 dockers' dispute in Liverpool, in which solidarity strikes at ports around the world demonstrated maritime unions' power to disrupt global commerce (Castree, 2000; Carter et al., 2003); the Teamsters' successful 1997 strike against UPS, which featured transnational union cooperation coordinated through the UPS World Council (Russo and Banks, 1999; Mazur, 2000); the transnational alliance launched in 1998 in an attempt to get mining giant Rio Tinto to abide by ILO conventions on labour rights (Goodman, 2004; Sadler and Fagan, 2004); countless new union-activist alliances forged in the heat of the 1999 anti-WTO protests in Seattle; and dozens of anti-sweatshop campaigns led by coalitions of unions, students and NGOs in Asia and Latin America (Johns and Vural, 2000; Anner, 2009).

Many of these were published in edited volumes. Gordon and Turner's (2000) Transnational Cooperation Among Labour Unions offered a handful of case studies of campaigns in export processing zones and global industries such as telecommunications, mining and energy, and mass media. The volume suggested that labour transnationalism need not be approached the same way as traditional industrial relations and could indeed be likened more to a social movement (Anner, 2000). Harrod and O'Brien's (2002) edited volume, Global Unions? Theory and Strategies of Organized Labour in the Global Political Economy, contributed several case studies as well. The authors attempted to fuse "the two 
IRs" (industrial relations and international relations) by portraying the transnational activities of organised labour as actively shaping global economic processes, as opposed to viewing labour as a passive victim of globalisation (Harrod and O'Brien, 2002), a theme prominent in the labour geography literature (discussed below).

Half a decade later, scholars began to develop a greater understanding not only of unions' transnational strategies but also of employers' vulnerabilities, reflecting the increasing use by unions of research into the operations of TNCs. Another edited volume sought to address the "extreme shortage of quality academic research" on labour transnationalism, particularly transnational campaigns based on comprehensive corporate research (Bronfenbrenner, 2007: 6). While its case studies covered several different industries and countries, including previously neglected developments in the South, the volume still did not provide a clear sense of the extent to which its nine separate and very different cases studies were analytically comparable. A 2013 volume edited by Fairbrother, Hennebert and Lévesque titled Transnational Trade Unionism: Building Union Power contributed another set of case studies that discuss aspects of labour transnationalism related to global production networks, global framework agreements and North-South cooperation. However, it too lacked a strong theoretical compass to guide the reader's interpretation of workers' transnational strategies, including why they develop and why some strategies are more effective than others. Yet another edited volume, Labour and Transnational Action in Times of Crisis (Bieler et al., 2015), examined global labour activism in the wake of the 2008 global financial crisis, depicting both labour and capital as being on the defensive. While its emphasis on labour's agency is an important contribution, its chapters are only loosely connected and not united under a clear theoretical framework.

Overall, despite a welcome shift toward careful examinations of actual transnational labour campaigns, fifteen years of largely separate case studies still offer more "trees" than "forest" (Burgoon and Jacoby, 2004). This group of NGLS scholars has thus been criticised for their "attempts to provide case study accounts ... without making explicit the analytical implications of how such phenomena should be conceptualised within the broader dynamics of global capitalism" (Taylor, 2009: 449). Nevertheless, there are important exceptions.

One example in the strategy-focused NGLS group are Marxist geographers such as Andrew Herod and Jane Wills. They built on the conceptual apparatus of forebears like David Harvey, Doreen Massey and Edward Soja, who theorised space not only as an outcome of social relations but as part of the equation that generates those relations. This foundation has been central to NGLS scholars who have benefitted from these theoretical insights about the spatial organisation of workers and the spatial vulnerabilities of global employers. Thus, we have seen an explosion of interest in ways that spatial dynamics might inhibit or help workers build power (Herod, 1998, 2001, 2003; Wills, 1998, 2002; Waterman and Wills, 2002). In particular, the subfield of labour geography "portrays labour as a proactive force and workers as active agents in the making and shaping of the geographies of capitalism" (Lier, 2007: 829). Labour geographers have been the main scholars to investigate strategies that exploit the spatial matrix of global capital (Wills, 2004; Selwyn, 2007, 2011;

Global Labour Journal, 2017, 8(3), Page 208 
Anderson, 2009; Coe and Jordhus-Lier, 2011). These strategies often involve workers striking along specific choke points on global production and service delivery networks. Selwyn $(2007,2011)$, for example, showed how agricultural workers enhance their bargaining power by deliberately varying the speed at which they pick fresh fruit, thus reducing its value further down the supply chain, given the short shelf life of export-quality produce.

Labour geographers are not the only scholars who have been keen to point out how the structure of capitalism influences worker strategies in transnational campaigns. For instance, Kay (2011) demonstrated the paradoxical rise of labour transnationalism as a result of the North American Free Trade Agreement (NAFTA), which created a "transnational political opportunity structure" that facilitated more substantive US-Mexican labour collaboration than the close ties of each country's formal union movements ever had. Kay's findings were so interesting because they added an important twist to the received wisdom about the impact of free trade agreements on organised labour. Along similar lines, Anner (2011) showed how the global restructuring of manufacturing processes produced unanticipated opportunities for transnational collaboration among labour activists in Latin America and North America. Likewise, Brookes (2013) illustrated how the growing complexity of global value chains, national and international institutions, and transnational stakeholder networks have created new sources of power for workers and unions embedded in the global economy.

The seductive notion that global capital will provide its own gravediggers thus runs through much of the strategy-focused NGLS literature. In addition to this general Marxian orientation, NGLS scholars, including many of those cited above, have also drawn a great deal on Silver's (2003) refinement of Erik Olin Wright's (2000) concepts of structural and associational power. They describe, respectively, the power that accrues to workers based on their economic and geographic position in the world economy and the power workers have by virtue of their organisations. These scholars not only analyse labour transnationalism through the lens of structural and associational power; they have also made their own contributions to theoretical development by refining or expanding on the power framework (e.g., Chun, 2009; Selwyn, 2011; Brookes, 2013; Schmalz and Dörre, 2014).

Not all strategy-focused NGLS scholars emphasise global capitalism's inherent contradictions. Some examine instead how, rather than taking advantage of opportunity structures arising ironically out of economic globalisation, transnational labour activists have actually created their own spaces for collective action by building international institutions, such as corporate codes of conduct or global framework agreements. These scholars thus take a different theoretical point of departure from those discussed above, who frame labour transnationalism in terms of either social movement unionism or workers' exploitation of capital's built-in vulnerabilities. Recalling one of the main backbones of early globalisation studies, this other subset of scholars implicitly or explicitly views national states as declining in their capacities to protect labour rights (Tilly, 1995). Hence, building international institutions - sets of rules and regulations not bounded by national borders - seems a sensible way for transnational labour activists to proceed. The most recent and significant attempts

Global Labour Journal, 2017, 8(3), Page 209 
to globalise labour relations have been through the Global Unions, which attempt to create what Müller-Jentsch (2004) called an "arena", a contested space for global industrial relations. Typically, Global Unions attempt to force major corporations to sign a framework agreement, a policy instrument that requires signatories to adhere to a set of labour standards. As the number of framework agreements have increased, so has the literature to explain their relevance (Fichter and McCallum, 2015).

Some early scholarship focused on GFAs as the clarion call of a new frontier in industrial relations and social dialogue relations (Wills, 2002; Hammer, 2005; Riisgaard, 2005). A later perspective viewed GFAs more modestly as instruments for private governance. In the absence of a regulatory apparatus that could safeguard workers at the global level, GFAs represented a mechanism for upholding basic standards and conditions that most national legal systems do not provide, especially in the Global South (Schomann et al, 2008; Papadakis, 2011). Still others have focused on the potential for GFAs to assist workers in organising unions and on the application of GFAs beyond the companies' home countries, as labour rights generally become weaker the further one moves from the corporate centre (Stevis and Boswell, 2008). Gradually, as scholars grew familiar with more sober possibilities, the literature turned toward an analysis of how GFAs were actually implemented (Fichter and McCallum, 2015).

Overall, the scholarly focus on strategy has functioned like a critical appraisal of a "tool kit" that workers and their organisations use to overcome the deficiencies of a national approach. In showcasing the diversity of transnational tactics labour has at its disposal, this stock-taking of different strategies has provided a literature rich in empirical description. We still do not know, however, why only some workers have taken advantage of new strategic opportunities and why workers' transnational strategies only rarely accomplish their goals. That will require more comparative case studies, one of several recommendations we address below.

\section{Next Steps for the New Global Labour Studies}

The areas of scholarship reviewed above make worthwhile contributions that enhance our understanding of the alliances, organisations and campaigns that comprise the new labour transnationalism. The theoretical literature inspired by Marx and Polanyi connects labour's transnational activities to broad themes: global inequality, societal backlash and the future of capitalism - the big questions of our time. The strategy-focused literature sheds light on labour transnationalism "on the ground" through empirical investigations of the actors, interests and interactions driving this phenomenon. However, we feel that NGLS scholars would make a greater contribution to our understanding of labour transnationalism, and to the varied disciplines from which they hail, if they made more explicit critiques of the core of their respective traditions sociology, political economy, international relations, political science, labour studies and others. Engaging the theoretical foci of these disciplines - the nature of the state, the viability of private governance, the disappearance of social protections, the growth of social movements, and the end of 
neo-liberalism - would help not only to clarify the positions of NGLS scholars, but also to broaden our collective understanding of why labour transnationalism matters to social science.

In many ways, this call echoes that of some employment relations (ER) scholars who still work in a field overwhelmingly dominated by national perspectives (Jackson, Kuruvilla and Frege, 2013). While Jackson and his colleagues are somewhat optimistic that ER thinkers will increasingly contribute to the wider social sciences, we feel it will not happen naturally. The subfield barriers seem at times to be higher than those separating the disciplines.

For instance, while most NGLS scholars acknowledge the structural constraints that may limit national governments' capacities to protect labour rights, they have yet to fully engage with the vast political science literature on private governance, which considers when and how corporations abide by regulations set forth by other non-state actors (Brammer, Jackson and Matten, 2012; Locke, 2013). The NGLS also developed largely in parallel with what is by now a mature body of literature in comparative and international political economy on corporate strategy and institutional change. Those literatures overlook labour as a causal factor in the construction of a political-economic landscape. The NGLS, by placing labour movements and workers at the centre of a social process to create a global division of labour, makes an implicit critique of this absence by rendering visible a conflict which is often ignored as a background condition.

McCallum's (2013) work goes some way toward responding to this challenge by directly addressing literatures in the mainstream political science canon on governance. Still, his concepts remain under-theorised. For instance, he argues that new forms of labour transnationalism typically take the form of "governance struggles" which emphasise the creation not of new rights but of new rules of engagement with global capital. It is not clear, however, what distinguishes rules from rights, why one is necessarily preferable to the other, and whether the new rules forged out of governance struggles can function autonomously in the private realm or ultimately require the coercive backing of states. Deeper engagement with the work of historical institutionalists in comparative political economy, who have demonstrated how and why rules (institutions) transform into formal rights over time (Thelen, 1999; Brammer et al., 2012), could enhance our understanding of governance struggles and their outcomes. ${ }^{1}$

Likewise, there is surprisingly little integration of the NGLS literature with the well-developed sociological literature on transnational advocacy networks (TANs). ${ }^{2}$ These separate theoretical paths are in part a legacy of the foundational work on transnational advocacy, Keck and Sikkink's (1998)

\footnotetext{
${ }^{1}$ One well-known example of rules-on-paper being transformed into de facto rights is how the Bill of Rights in the US Constitution, which was initially applied only to a small set of landowning white men, over time came to actually protect the rights of women, African Americans and many others, thanks to civil rights activists engaging in processes of institutional change.

2 In the original boomerang model, local actors blocked from political action in their home state activate an international network of NGOs, activist groups and other supporters who pressure more powerful states to intervene in the first state's domestic affairs. In the process TANs use ideas, values and norms to persuade states to reformulate their interests and alter their behaviour.
} 
Activists Beyond Borders, which explicitly discounted the potential of organised labour to participate meaningfully in TANs. Yet while the early work on TANs portrayed labour as an "old" movement, qualitatively distinct from the heterogeneous mix of principled actors that comprise TANs, more recent scholarship has revealed that transnational labour campaigns sometimes resemble TANs in strategy, if not form (Armbruster-Sandoval, 2005). Workers have used transnational advocacy to convince states to comply with internationally recognised union rights (Kang, 2012), and many corporate campaigns have involved unions collaborating across borders with consumers, shareholders, students, environmentalists and other actors outside the labour movement (Johns and Vural, 2000; Goodman, 2004; Sadler, 2004; Brookes, 2013).

Confusion over the relationship between labour transnationalism and TANs is a symptom of a more fundamental problem in the strategy-focused NGLS literature: how exactly to conceptualise labour as a transnational actor. Unlike the Polanyi-inspired scholars, who conceive of labour transnationalism specifically as a global counterweight, the strategy-focused scholars define labour transnationalism in several different ways. This varied conceptualisation is evident not only in the terminology used in the NGLS but also in the use of very different units of analysis, which include movements, campaigns, bilateral alliances, multilateral alliances, Global Unions, GFAs and individual unions. Because we lack clear criteria for categorising the wide range of empirically observed types of labour transnationalism, one cannot be sure whether, for example, transnational labour alliances "that are established and stable but do very little" are directly comparable with labour alliances "that are ephemeral but capture more of the excitement of a social movement" (Hyde and Ressaissi, 2009: 10).

Conceptualisation cannot remain an open question. Until scholars can better categorise different instances of labour transnationalism, neither small-N comparative case studies nor large-N statistical analyses can be carried out effectively. Separating apples from baseballs - that is, answering the question, "What is this a case of?" - not only makes comparison possible but also alerts researchers to the relevant larger literature that might already offer some answers to the questions NGLS scholars have asked. Moving from trees to forest will thus require a more conscious typology of labour transnationalism, which would help establish clearer criteria for comparative analysis. Comparative analyses, especially controlled comparisons, remain one of the most essential tools for theory development in the social sciences (Slater and Ziblatt, 2013), and their increased use in the NGLS would, in turn, facilitate the development of middle-range theories that strike a productive balance between abstract explanation and detailed empirics. Put simply, this type of theory building calls for an iterative process in which the researcher necessarily moves back and forth between theory and cases. The more we know about concrete cases, the more equipped we will be to develop critical social science theories that explain the causes and consequences of labour transnationalism. Likewise, the better the theories we have in the NGLS, the better we will be at understanding realworld events and "getting the cases right.".

In general, we believe that the field, diverse as it is, has been largely, and for some good reasons, pointed inward. However, it might be time to return to the beginning. The NILS field 
emerged as a critique of mainstream political economy, presenting challenges to that field that were explicit, if incomplete. The NGLS, by contrast, appears to have been more of a reaction to "real-life" labour activity, at times providing more description and observation than academic critique. Now is the time to pick up where the NILS scholars left off by combining NGLS scholars' strengths in bigpicture theorising and case study research.

Asking and answering more big questions, drawing more comparisons and generating middlerange theories, all of which NGLS scholars are well-positioned to do, could not only illuminate strategic insights. It could also help piece together some key theoretical puzzles at the heart of the social sciences.

\section{Conclusion}

On one hand, the NGLS literature has evolved considerably since its emergence roughly two decades ago. Increasingly, scholars are paying serious attention to labour transnationalism initiated in the Global South (Burawoy, 2009) and are analysing more transnational labour activity occurring outside organised labour's traditional strongholds in manufacturing, particularly through greater attention to developments in the service sector. Significant contributions to theories inspired by Marx and Polanyi are another important accomplishment of the NGLS, as is the production of a wealth of empirical case studies.

On the other hand, gaps in the literature indicate that the NGLS is still in its adolescence. The impulse, in one strand of literature, to tie the recent rise in cross-border labour collaboration to abstract theories of a "second great transformation" are understandable, but empirically unfounded. As McCallum (2013) has argued, the double movement concept "provides the relationship between global capitalism and worker power a coherence it does not possess". The related impulse, to focus more narrowly on actual instances of transnational labour cooperation, has yielded important but mostly ungeneralisable findings. We have therefore argued for more middle-range theories and closer engagement with social science literature outside the labour studies core to help answer larger questions pertinent to a wider range of scholars.

With the emergence of the new global labour studies, scholars have gained a wealth of knowledge about the actors and strategies involved in labour transnationalism. It is now time to refine that knowledge to attain a more complete understanding of labour transnationalism and its outcomes. We hope that the suggestions offered here are useful for that goal.

\section{REFERENCES}

Anderson, J. (2009) Labour's Lines of Flight: Rethinking the Vulnerabilities of 'Transnational Capital. Geoforum, 40(6): 959-968.

Anner, M. (2000) Local and Transnational Campaigns to End Sweatshop Practices. In Transnational Cooperation Among Labour Unions, edited by M.E. Gordon and L. Turner. Ithaca, NY: Cornell University Press.

Global Labour Journal, 2017, 8(3), Page 213 
Anner, M. (2009) Two Logics of Labor Organizing in the Global Apparel Industry. International Studies Quarterly, 53(3): 545-570. Available online at https://doi.org/10.1111/j.1468-2478.2009.00546.x.

Anner, M. (2011) Solidarity Transformed: Labour Responses to Globalisation and Crisis in Latin America. Ithaca, NY: Cornell University Press.

Armbruster-Sandoval, R. (2005) Workers of the World Unite? The Contemporary Anti-Sweatshop Movement and the Struggle for Social Justice in the Americas. Work and Occupations, 32(4): 464-485.

Bieler, A., R. Erne, D. Golden, I. Helle, K. Kjeldstadli, T. Matos and S. Stan (eds.) (2015) Labour and Transnational Action in Times of Crisis. London and New York: Rowman \& Littlefield International.

Bieler, A. and I. Lindberg (2010) Global Restructuring, Labour, and the Challenges for Transnational Solidarity. New York: Routledge.

Brammer, S., G. Jackson and D. Matten (2012) Corporate Social Responsibility and Institutional Theory: New Perspectives on Private Governance. Socio-Economic Review, 10(1): 3-28.

Bronfenbrenner, K. (2007) Global Unions: Challenging Transnational Capital Through Cross-border Campaigns. Ithaca, NY: Cornell University Press.

Brookes, M. (2013) Varieties of Power in Transnational Labour Alliances: An Analysis of Workers' Structural, Institutional, and Coalitional Power in the Global Economy. Labour Studies Journal, 38(3): 181-200.

Burawoy, M. (2009) The Global Turn: Lessons from Southern Labour Scholars and their Labour Movements. Work and Occupations, 36(2): 87-95.

Burawoy, M. (2010) From Polanyi to Pollyanna: The False Optimism of Global Labour Studies. Global Labour Journal, 1(2): 301-313.

Burgoon, B. and W. Jacoby (2004) Patch-work Solidarity: Describing and Explaining US and European Labour Internationalism. Review of International Political Economy, 11: 849-879.

Carter, C., S. Clegg, J. Hogan and M. Kornberger (2003) The Polyphonic Spree: The Case of the Liverpool Dockers. Industrial Relations Journal, 34(4): 290-304.

Castree, N. (2000) Geographic Scale and Grass-roots Internationalism: The Liverpool Dock Dispute, 19951998. Economic Geography, 76(3): 272-292. Available online at https://doi.org/10.2307/144293.

Castree, N. (2007). Labour Geography: A Work in Progress. International Journal of Urban and Regional Research, 31(4), 853-862.

Chun, J.J. (2005). Public Dramas and the Politics of Justice. Work and Occupations, 32(4), 486-503.

Chun, J.J. (2009) Organizing at the Margins: The Symbolic Politics of Labor in South Korea and the United States. Ithaca, NY: Cornell University Press.

Clawson, D. (2010) "False" Optimism: The Key to Historic Breakthroughs? A Response to Michael Burawoy's "From Polanyi to Pollyanna: The False Optimism of Global Labour Studies". Global Labour Journal, 1(3): 398-400.

Coe, N.M. and D.C. Jordhus-Lier (2011) Constrained Agency? Re-evaluating the Geographies of Labour. Progress in Human Geography, 35(2): 211-233.

Cohen, R. (1980) The "New" International Labour Studies: A Definition. Working Paper Series 27. Montréal: Centre for Developing-Area Studies, McGill University. 
Cornfield, D.B. and H.J. McCammon (2003) Labour Revitalization: Global Perspectives and New Initiatives. Greenwich, CT: JAI Press.

Evans, P. (2008) Is an Alternative Globalisation Possible? Politics \& Society, 36(2): 271-305.

Evans, P. (2010) Is it Labour's Turn to Globalize? Twenty-first Century Opportunities and Strategic Responses. Global Labour Journal, 1(3): 352-379.

Fairbrother, P., M.-A. Hennebert and C. Lévesque (2013) Transnational Trade Unionism: Building Union Power. New York: Routledge.

Fichter, M. and J.K. McCallum (2015) Implementing Global Framework Agreements: The Limits of Social Partnership. Global Networks, 15(s1): S65-S85.

Goodman, J. (2004) Australia and Beyond: Targeting Rio Tinto. In Labour and Globalisation: Results and Prospects, edited by R. Munck. Liverpool: Liverpool University Press.

Gordon, M.E. and L. Turner (2000) Transnational Cooperation Among Labour Unions. Ithaca, NY: Cornell University Press.

Hammer, N. (2005) Global Framework Agreements: Global Industrial Relations between Rights and Bargaining. Transfer: European Review of Labour and Research, 11: 511-530.

Hardt, M. and A. Negri (2001) Empire. Cambridge, MS: Harvard University Press.

Harrod, J. and R. O'Brien (2002) Global Unions? Theory and Strategies of Organised Labour in the Global Political Economy. London: Routledge.

Herod, A. (1995) The Practice of International Labor Solidarity and the Geography of the Global Economy. Economic Geography, 71(4): 341-363.

Herod, A. (1998) Organizing the Landscape: Geographical Perspectives on Labour Unionism. Minneapolis: University of Minnesota Press.

Herod, A. (2001) Labour Geographies: Workers and the Landscapes of Capitalism. New York: Guilford Press.

Herod, A. (2003). Workers, Space, and Labour Geography. International Labour and Working-Class History, 64: $112-138$.

Hyde, A. and M. Ressaissi (2009) Unions Without Borders: Recent Developments in the Theory, Practice and Law of Transnational Unionism. Canadian Labour and Employment Law Journal, 14: 47-104.

Jackson, G., S. Kuruvilla and C. Frege (2013) Across Boundaries: The Global Challenges Facing Workers and Employment Research. British Journal of Industrial Relations, 51(3): 425-439.

Johns, R. and L. Vural (2000) Class, Geography, and the Consumerist Turn: UNITE and the Stop Sweatshops Campaign. Environment and Planning A, 32(7): 1193-1213.

Juravich, T. and K. Bronfenbrenner (1999) Ravenswood: The Steelworkers' Victory and the Revival of American Labour. Ithaca, NY: ILR Press.

Kang, S.L. (2012) Human Rights and Labour Solidarity: Trade Unions in the Global Economy. Philadelphia, PA: University of Pennsylvania Press.

Kay, T. (2011) NAFTA and the Politics of Labour Transnationalism. Cambridge, MA: Cambridge University Press. 
Keck, M.E. and K. Sikkink (1998). Activists Beyond Borders: Advocacy Networks in International Politics. Ithaca, NY: Cornell University Press.

Lerner, S. (2007) Global Corporations, Global Unions. New Labour Forum, 16(1): 23-37.

Lier, D.C. (2007) Places of Work, Scales of Organising: A Review of Labour Geography. Geography Compass, 1(4): 814-833.

Locke, R.M. (2013) The Promise and Limits of Private Power: Promoting Labor Standards in a Global Economy. New York: Cambridge University Press.

Mazur, J. (2000) Labour's New Internationalism. Foreign Affairs, 79(1): 79-93.

McCallum, J.K. (2013) Global Unions, Local Power: The New Spirit of Transnational Labour Organizing. Ithaca, NY: Cornell University Press.

Moody, K. (1997) Workers in a Lean World: Unions in the International Economy. London: Verso.

Muiller-Jentsch, W. (2004) Theoretical Approaches to Industrial Relations. In Theoretical Perspectives on Work and the Employment Relationship, edited by B.E. Kaufman. Champaign, IL: Industrial Relations Research Association.

Munck, R. (2002) Globalisation and Labour: The New Great Transformation. New York: Zed Books.

Munck, R. (1988) The New International Labour Studies: An Introduction. London and Atlantic Highlands, N.J.: Zed Books.

Papadakis, K.P. (2011) Shaping Global Industrial Relations. The Impact of International Framework Agreements. New York: Palgrave Macmillan and the International Labour Office.

Polanyi, K. (2001 [1944]) The Great Transformation. Second ed. Boston: Beacon Press.

Riisaard, L. (2005) International Framework Agreements: A New Model for Securing Workers Rights? Industrial Relations, 44: 707-737.

Russo, J. and A. Banks (1999) How Teamsters Took the UPS Strike Overseas. Working USA, 2(5): 75-87.

Sadler, D. (2004) Trade Unions, Coalitions and Communities: Australia's Construction, Forestry, Mining and Energy Union and the International Stakeholder Campaign Against Rio Tinto. Geoforum, 35(1): 35-46.

Sadler, D. and B. Fagan (2004) Australian Trade Unions and the Politics of Scale: Reconstructing the Spatiality of Industrial Relations. Economic Geography, 80(1): 23-44.

Schömann, I., A. Sobzack, V. Eckhard and P. Wilke (2008) Global Framework Agreements: New Paths to Workers' Participation in Multinationals' Governance? European Review of Labour and Research, 14: 111-126.

Schmalz, S. and K. Dörre (2014) Der Machtressourcenansatz: Ein Instrument zur Analyse gewerkschaftlichen Handlungsvermögens. Industrielle Beqiehungen / The German Journal of Industrial Relations, 21(3): 217-237.

Seidman, G. (2008) Transnational Labour Campaigns: Can the Logic of the Market be Turned against Itself? Development and Change, 39(6): 991-1003.

Selwyn, B. (2007) Labour Process and Workers' Bargaining Power in Export Grape Production, North East Brazil. Journal of Agrarian Change, 7(4): 526-553.

Selwyn, B. (2011) Beyond Firm-Centrism: Re-integrating Labour and Capitalism into Global Commodity Chain Analysis. Joumal of Economic Geography, 12(1): 205-226. 
Silver, B.J. (2003) Forces of Labour: Workers' Movements and Globalisation Since 1870. New York: Cambridge University Press.

Slater, D. and D. Ziblatt (2013) The Enduring Indispensability of the Controlled Comparison. Comparative Political Studies, 46(10): 1301-1327.

Stevis, D. (2009) Global Framework Agreements: Globalizing or Escaping European Industrial Relations? Paper presented at the Law and Society Conference, Denver, May 29-31.

Stevis, D. and T. Boswell (2008) Globalisation and Labour: Democratizing Global Governance. Lanham, MD: Rowman \& Littlefield.

Taylor, M. (2009) Who Works for Globalisation? The Challenges and Possibilities for International Labour Studies. Third World Quarterly, 30(3): 435-452.

Thelen, K. (1999) Historical Institutionalism in Comparative Politics. Annual Review of Political Science, 2(1), 369-404.

Tilly, C. (1995) Globalisation Threatens Labour's Rights. International Labour and Working-Class History, 47(1): $1-23$.

Waterman, P. (1998) The Second Coming of Proletarian Internationalism? A Review of Recent Resources. European Journal of Industrial Relations, 4(3): 349-377.

Waterman, P. (2001) Globalisation, Social Movements and the New Internationalisms. New York: Continuum International.

Waterman, P. and J. Wills (2002) Space, Place and the New Labour Internationalisms: Beyond the Fragments? Antipode, 33(3): 305-311.

Webster, E., R. Lambert and A. Beziudenhout (2008). Grounding Globalisation: Labour in the Age of Insecurity. Oxford: John Wiley \& Sons.

Wills, J. (1998) Taking on the Cosmo Corps? Experiments in Transnational Labour Organization. Economic Geography, 74(2): 111-130.

Wills, J. (2002) Bargaining for the Space to Organize in the Global Economy: A Review of the Accor-IUF Trade Union Rights Agreement. Review of International Political Economy, 9(4): 675-700.

Wills, J. (2004) Re-Scaling Trade Union Organisation. In Labour and Globalisation: Results and Prospects, edited by R. Munck. Liverpool: Liverpool University Press.

Wright, E.O. (2000) Working-Class Power, Capitalist-Class Interests, and Class Compromise. American Journal of Sociology, 105(4): 957-1002.

Global Labour Journal, 2017, 8(3), Page 217 


\section{BIOGRAPHICAL NOTES}

MARISSA BROOKES is assistant professor of Political Science at the University of California, Riverside. Her work appears in Comparative Political Studies, Development and Change, the Labor Studies Journal, and PS: Political Science \& Politics. [Email: Marissa.brookes@ucr.edu]

JAmie K. MCCALlum is assistant professor of Sociology at Middlebury College. His book, Global Unions, Local Power: The New Spirit of Transnational Labor Organizing (Cornell, 2013), won the best book award in 2014 from the Labor and Labor Movements section of the American Sociological Association. [Email: mccallum@,middlebury.edu] 